\title{
DIDACTICS OF TECHNICAL SUBJECTS AT SECONDARY SCHOOLS - DEVELOPMENT, STATE AND PROSPECTS
}

Pavel PECINA*, Masarykova Univerzita, Pedagogická fakulta, Brno Petr SLADEK* , Masarykova Univerzita, Pedagogická fakulta, Brno

Přijato: 27. 10. 2015 / Akceptováno: 11. 12. 2015

Typ článku: Teoretická studie

DOI: $10.5507 /$ jtie.2016.003

Abstract: The intention of the present review study is to outline the origin and historical development of didactics of technical subjects at secondary schools, further and analyze the current situation and suggest the possibility of its further development. Given the scope of the issue, attention is focused on key moments that characterize the main trends of didactics with emphasis on the importance of research and development activities in this area. Presented are selected research findings on the issue of teaching methods and technical creativity of students in vocational technical subjects in secondary schools.

Key words: Subject didactics, didactics of technical subjects, engineering education, historical development of didactics of technical subjects, current status, scientific research in the didactics of technical subjects.

\section{DIDAKTIKA ODBORNÝCH TECHNICKÝCH PŘEDMĚTŮ NA STŘEDNÍCH ŠKOLÁCH - VÝVOJ, STAV A PERSPEKTIVY}

Resumé: Záměrem předložené přehledové studie je nastínit vznik a historický vývoj oborové didaktiky technických předmétů na středních školách, dále potom analyzovat jeji současný stav a naznačit možnosti jejího dalšiho vývoje. Sohledem na rozsah dané problematiky je pozornost zaměrena na kličové momenty, které charakterizuji hlavní tendence vývoje této oborové didaktiky s důrazem na význam vědeckovýzkumné činnosti v této oblasti. Prezentována jsou $i$ vybraná výzkumná zjištěni k problematice výukových metod a technické tvořivosti žáků vodborných technických předmětech na středních školách.

Klíčová slova: Oborová didaktika, didaktika technických předmětů, inženýrská pedagogika, historický vývoj didaktiky technických předmětů, současný stav, vědeckovýzkumná činnost v didaktice odborných technických předmětů.

5. (1) This journal was approved on 2015-04-23 according to ERIH

*Autor pro korespondenci: ppecina@ped.muni.cz 


\section{1 Úvod}

Didaktika odborných technických předmětů je relativně mladou pedagogickou disciplínou, která v současnosti zaznamenává společně s dalšími oborovými didaktikami určitou renesanci a stává se respektovanou oblastí poznání naší reality. Důkazem vzestupu oborových didaktik je existence stále pracovní skupiny akreditační komise pro oborové didaktiky a její aktivity (http://www.akreditacnikomise.cz/cs/oborovedidaktiky.html). Stejně jako ostatní oborové didaktiky prošla vývojem, který odrážel různá pojetí a strukturace této disciplíny. Její zdůvodnění, význam a potřebnost vyplývá $\mathrm{z}$ vážnosti a potřebnosti rozvíjející se technické reality kolem nás. Momentální stav však není uspokojivý, můžeme hovořit, že z určitého úhlu pohledu se nachází na svém „startu“ svého dalšího rozvoje v podmínkách rychle se měnícího světa a pod vlivem rozvoje soudobých technologií. Je jen na komunitě odborníků v oblasti odborného vzdělávání jakým směrem se bude ubírat její další vývoj.

V souvislosti s vážností této problematiky jsme si stanovili za cíl zmapovat hlavní momenty vývoje didaktiky technických předmětů $\mathrm{v}$ České republice $\mathrm{s}$ přesahem do zahraničí (Slovensko, Německo), včetně zamyšlení nad jejím dalším vývojem. Zaměřili jsme se přitom na klíčové momenty jejího vývoje $\mathrm{s}$ ohledem na specifičnost a interdisciplinaritu této oblasti poznání s důrazem na vědeckovýzkumnou činnost.

Studie může být inspirativní pro oborové didaktiky se zaměřením na technické předměty na středních školách.

\section{Použité výzkumné metody}

Při zpracování studie k řešené problematice jsme využili analýzy dostupných domácích a vybraných zahraničních pramenů (Slovensko, SRN, USA). Vycházeli jsme i ze zkušeností sítě našich partnerských středních škol. Prezentovaný výzkum byl realizován s pomocí empirických metod (ve fázi sběru dat dotazník, řízený rozhovor, ve fázi analýzy získaných údajů jsme použili statistické metody, součty, průměry a test dobré shody chí - kvadrát).

\section{Základní východiska, vymezení řešené problematiky}

$\mathrm{V}$ této části se zaměříme na vymezení pojmů didaktika odborných technických předmětů a jejího vztahu $\mathrm{k}$ dalším vědním disciplínám a pokusíme se tedy vymezit interdisciplinární diskurz, ve kterém se tato oborová didaktika pohybuje (nebo by se měla pohybovat). Jak poukazují I. Stuchlíková a T. Janík, oborová didaktika není pouhým volným kompilátem pedagogicko-psychologických disciplín a př́islušného oboru ale disciplínou, která $\mathrm{v}$ soudobém pojetí hledá a zpřesňuje odpovědi na otázky proč, co, jak, koho, kdy a kde vyučovat (Stuchlíková, Janík, 2015).

Abychom vymezili předmět zájmu didaktiky odborných technických předmětů, je třeba přiblížit související pojmy a zasadit její působnost do širších souvislostí. Posláním středních odborných škol je připravovat žáky na výkon daného povolání. Základními složkami edukační činnosti je oblast všeobecného vzdělávání a odborného vzdělávání. Do rámce odborného vzdělávání řadíme teoretickou odbornou př́íravu na poli teoretických odborných předmětů a oblast praktického vyučování, kam řadíme veškerou praktickou př́pravu (odborný výcvik, všechna, cvičení, odborná praxe). V oblasti odborných teoretických předmětů existují dvě velké skupiny - teoretické 
odborné technické předměty a odborné předměty $\mathrm{v}$ zaměření obchodu a služeb (Pecina, 2014). Lze diskutovat i o zařazení třetí skupiny odborných předmětů, které nelze jednoznačně zařadit do některé předešlé skupiny (např. zemědělské a zdravotní odborné předměty, předměty policejní prípravy apod.). $\mathrm{Z}$ uvedeného vyplývá, že úloha didaktiky odborných technických předmětů není jednoduchá. Jedná se o skupinovou oborovou didaktiku s velmi širokým záběrem. Blízká je i didaktika technické výchovy pro základni vzdělávání (resp. didaktika technických předmètů ve všeobecném vzdělávání). Se středoškolskou didaktikou odborných technických předmětů má mnoho společných prvků, nicméně se jedná o jinou oblast oborové didaktiky.

Didaktika odborných technických predmětů představuje disciplínu, která aplikuje obecně didaktické poznatky na skupinu technických odborných předmětů na středních školách. Podle J. Bajtoše (1999) je didaktika technických předmětů disciplínou, která zkoumá specifické zákonitosti technických odborných předmětů na středních školách. Její strukturu tvoří cíle, obsah, organizace, formy, metody, zásady a prostředky vyučování (Bajtoš, 1999). M. Čadílek (2005) definuje didaktiku odborných technických předmětů jako disciplínu, která zkoumá obsah a průběh vzdělávacího procesu včetně didaktické transformace výsledků technických věd. Podstata transformace spočívá ve formulaci cílů vzdělávání, výběru teoretických i praktických poznatků a jejich uspořádání do didaktické soustavy (Čadílek, 2005, s. 12). „Nejbliže je současnému pojetí oborových didaktik definice, která uvádí, že didaktika technických predmětů se zabývá otázkami požadavkỉ praxe a trhu práce na př́pravu kvalifikovaných technikü, stanovováním výukových cílů, obsahu výuky, aplikaci didaktických zásad, pouček, pravidel, výukových metod, organizačnich forem a materiálnich prostředkü na výuku technických předmètů na středních školách. Jeji pole působnosti zahrnuje otázky spojené s požadavky na učitele technických předmětù, žáky technických oborù a otázky spojené $s$ výchovným působením ve výuce (výchova $k$ technické tvořivosti, rozvoj formativnich stránek osobnosti, morální výchova apod.). Neméně dưležité je re rěsení koncepčních otázek středoškolského technického vzdèlávání, otázek souvisejicich s obory vzdèláni a dále potom $i$ otázky souvisejicí $s$ profesním vzdéláváním, profesními kvalifikacemi, celoživotním vzdèláváním a rekvalifikacemi " (Pecina, Sládek, 2013). Pro oborovou didaktiku technických předmětů (a obecně oborové didaktiky) jsou důležité dva momenty. Vazba přechodu a aplikace obecného na zvláštní a zvláštního na konkrétní (rozumí se tím samožrejmé $\mathrm{v}$ oblasti vzdělávání $\mathrm{i}$ výchovy). Zkoumají objektivní zákonitosti výuky daného oboru. Je však nutné doplnit i jejich subjektivní charakter, protože vychází ze zkušeností učitelů. Východiskem didaktiky technických předmětů př́ślušného stupně školy (střední škola) tedy nejsou vybrané konkrétní vyučovací technické předměty, ale soubor technických vědních oborů se svým obsahem a specifickými potřebami vycházejícími z požadavku na profil absolventa. Na úroveň vyučovacích předmětů (předmětových didaktik) se však dostáváme sekundárně v aplikační rovině (specifika využití konkrétních vyučovacích prostředků, konkrétní obsah výuky, aplikační modelové př́klady apod.). Mezi oborovou didaktikou a předmětovou didaktikou technických předmětů je silná vnitrooborová vazba. Dále je třeba zdůraznit, že oborová didaktika je do značné míry odrazem specifik, metod a obsahu př́ślušných technických věd. $Z$ tohoto důvodu zdůrazňuje J. Kropáč na fakt, že existuje společná didaktika pro oblast technických věd (Kropáč, 2004). 
Jako interdisciplinární věda má úzký vztah nejen k obecně pedagogickým disciplínám a obecné didaktice ale $\mathrm{i} \mathrm{k}$ technickým vědám, které ji poskytují manipulační prostor v oblasti specifik, aplikace cílů, obsahu, metod, forem a prostředků ve výuce technických předmětů a to na bázi komunikace při zprostředkování aktuálních a reálnou praxi reflektujících poznatků. Následující schéma (Schéma 1) vyjadřuje vazbu mezi obecně pedagogickými disciplínami, pedagogickou psychologií, technickými vědami a oborovou didaktikou technických předmětů a předmětovými didaktikami technických předmětů. Poznatky širší oborové didaktiky využívají učitelé technických předmětů v pedagogické praxi.

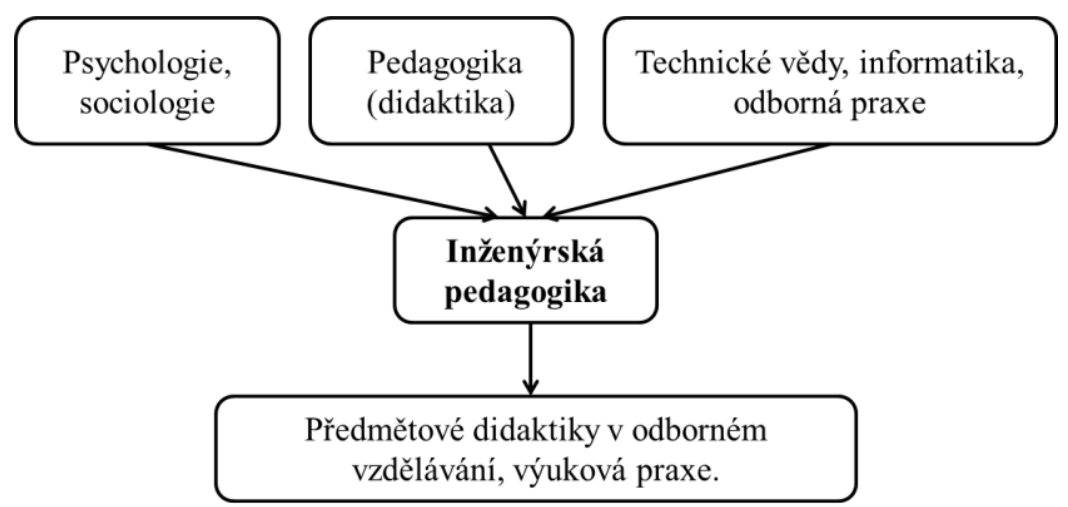

Schéma 1: Vztah didaktiky technických předmětů k dalším vědám

\section{Historický vývoj didaktiky odborných technických předmětů}

Vývoj didaktiky odborných technických předmětů byl ovlivněn zčásti obecnými tendencemi ve vývoji pedagogických disciplín a oborových didaktik a zčásti vývojem technických věd i vývojem politických a školských systémů. Paralelně $s$ vývojem didaktiky odborných technických předmětu se od druhé poloviny 20. století v zemích východního bloku vyvíjí i didaktika technické výchovy pro základni vzdèláváni (didaktika technických predmètù ve všeobecném vzdělávání). Jak již bylo zmíněno se středoškolskou didaktikou odborných technických předmětů má mnoho společných prvků a styčných bodů v oblasti výukových cílů, obsahu výuky i technologie výuky. Primárně se však jedná o jiný obor se svými specifiky a zaměřením. Touto oblasti se nebudeme podrobněji zabývat, protože přesahuje rámec této studie.

Do poloviny dvacátého století nelze uvažovat o existenci centrálního systému vzdělávání učitelů technických předmětů a tím i oborové didaktiky odborných technických předmětů. Technické vzdělávání realizovali zejména technici nebo řemeslníci, kteří připravovali budoucí pracovníky $\mathrm{v}$ př́slušné profesi. Vznik a systematický rozvoj vzniká v padesátých letech dvacátého století, kdy bylo zavedeno pedagogické vzdělávání inženýrů, učitelů technických předmětů. $\mathrm{V}$ průběhu vývoje didaktiky odborných technických předmětů pro středoškolské vzdělávání vznikla 
optimalizovaná vědní disciplína - inženýrská pedagogika. Její vznik je datován do šedesátých let dvacátého století (Německá demokratická republika). V roce 1972 vznikla společnost pro inženýrskou pedagogiku (IGIP - Rakousko). Další vývoj v 80. letech dvacátého století vyústil ve sjednocení doplňující pedagogické př́pravy pro neučitelské obory.

V České republice vznikala v 50. letech 20. století studijní a informační střediska pro hospodářské nauky odborných škol, jejichž cílem byla podpora výuky na ekonomických a dalších odborných školách. V následujícím období vznikl výzkumný ústav odborného školství, v jehož působnosti byly i otázky odborného technického vzdělávání. Dalším mezníkem byla polovina 60 . let, kdy tehdejší ministerstvo školství vydalo směrnici o doplňujícím pedagogickém studiu a došlo ke zř́zení kateder a kabinetů pedagogiky na neučitelských vysokých školách. V 70. letech byly publikovány některé př́nosné studie, které lze zařadit do rámce odborného technického vzdělávání (Vlášek, 1976, Vlášek, Průcha, 1978, Průcha, 1978). Studie vycházeli z empirických výzkumů založených na systém výuky odborných technických předmětů a na proces osvojování psychomotorických dovedností v praktické př́pravě technických oborů (Vlášek, 1976, Vlášek, Průcha, 1978).

Po roce 1989 dochází k politickým a společenským změnám, které výrazně zasahují i do vývoje oborových didaktik. Dochází k odklonu od komunistického systému výchovy a jednostranné orientace na sovětskou a východní pedagogiku. Oborovým didaktikům se tak otevřela brána $\mathrm{k}$ západním zemím a možnost čerpat informace a zkušenosti z vyspělých západních zemí. V 90 . letech dochází $\mathrm{k}$ určité stagnaci, která je dána nerespektováním oborové didaktiky jako vědní disciplíny dalšími obory. Tuto tendenci zaznamenáváme i u dalších oborových didaktik (např. didaktika fyziky, chemie a další). V 90. letech jsou České republice i na Slovensku publikovány některé učební texty, které se snaží reflektovat aktuální stav řešené problematiky. Vznikají práce I. Turka (1990), A. Melezinka (1994), J. Kropáče (1996), J. Bajtoše (1999) a M. Čadílka (1995) a J. Drahovzala (1997). Zaznamenáváme i monografie, které rozpracovávají některá dílčí témata. V oblasti problémové výuky je to práce F. Mošny a Z. Rádla (1996).

Období po roce 2000 je ve znamení kurikulární reformy a zavádění Rámcových vzdělávacích programů do vzdělávací praxe středních odborných škol. V této době vznikají opět některé učební texty a práce vycházející z této reformy. Autorem řady materiálů je Národní ústav odborného vzdělávání (dnes Národní ustav vzdělávání).

$\mathrm{V}$ průběhu vývoje zaznamenáváme různé př́istupy $\mathrm{k}$ názvu disciplíny. Nejprve se hovořilo o metodice. Poté vznikla označení didaktika učebního předmětu, metadidaktika, oborová didaktika, ontodidaktika, teorie vyučování předmětům všeobecně vzdělávací a odborné povahy, didaktika odborných předmětů, didaktika technických předmětů. Na úrovni oborů $\mathrm{v}$ širším pojetí vznikla i další označení, která jsou zaměřena na řešení interdisciplinárních vztahů ve vědě. J. Trna proto použíá pojem mezioborová didaktika (Trna, 2005). Vzniklo i označení obecná oborová didaktika, která se zaměřuje na obecné otázky společné pro oborové didaktiky. Pojem metodika je zúžené chápání této disciplíny, protože je odvozen od pojmu metoda. Lze jej však používat i dnes v př́padě zpracování metodik (např. metodika výuky tématu, tematického celku apod.). V 70. letech byl oficiálně používán název teorie vyučování předmětům všeobecně vzdělávací a odborné povahy. $\mathrm{V}$ té době to byl úředně stanovený název oborové 
didaktiky jako vědní disciplíny. Toto označení spojuje předměty všeobecné vzdělávací a odborné. Avšak jen skupina odborných předmětů v současné době představuje široké pole vědních disciplín a to $\mathrm{v}$ oborech technických, oborech obchodu a služeb, oborech ekonomických, zdravotnických, zemědělských a dalších, které nelze zařadit do žádné uvedené skupiny (kriminalistika, státní správa apod.). Ani označení didaktika odborných předmětů nevystihuje podstatu problému. Proto $\mathrm{v}$ současné době používáme označení didaktika odborných technických předmětů nebo didaktika odborných předmětů technického charakteru (Friedmann, Pecina, 2013, Pecina, 2012).

$\mathrm{V}$ pojetí didaktiky odborných technických předmětů lze spatřovat některé důležité momenty. Po svém vzniku se vyvíjely jako praktické disciplíny, bez hlubšího vztahu $\mathrm{k}$ pedagogice jako vědě. Její náplň vytvářeli především zkušení učitelé z pedagogické praxe. To vyústilo v prakticizmus a prakticistické pojetí oborové didaktiky. V tomto duchu byly řešeny konkrétní otázky metodického charakteru bez hlubší vazby a provázanosti na vzdělávací systém a další související vědní disciplíny. Byly preferovány konkrétní postupy a návody, které učitelům usnadňovaly vyučovací činnost. Teoreticky fundovaná systematická metodická práce bohužel chyběla (Kilián, 2008). Toto aplikační pojetí oborové didaktiky je v současné době již překonané (Nezvalová, 2011). V současné době přistupujeme ke koncipování vědecko-tvưrčí oborové didaktiky technických předmětů. Oboroví didaktici technických předmětů se snaží dát této disciplíně pevný vědecký základ a vědecké zdůvodnění na základech odpovídajícího pedagogického výzkumu. Didaktika technických předmětů se tak snaží dát učitelům široce koncipované množství vyučovacích strategií (metod, forem a prostředků) a připravit je na odpovídající využivání těchto strategií při dosahování odpovídajících cílů a prostřednictvím odpovídajících vzdělávacích obsahů a za odpovídajících podmínek výuky a na základě mnohostranné komunikace mezi všemi činiteli výukového procesu (Kilián, 2008, Friedmann, Pecina, 2013). Toto pojetí je tedy analogií soudobého komunikačního pojetí oborové didaktiky, které výrazně ovlivňuje české didaktické myšlení (Píšová, 2011, Nezvalová, 2011).

\section{Současný stav}

V současné době se didaktice odborných technických předmětů v České republice věnují následující instituce:

- Instituty celoživotního vzdělávání na technických vysokých školách (VUT Brno, ČVUT Praha, Mendlova univerzita v Brně, Technická univerzita v Liberci a další.).

- Pracoviště připravující učitele odborných technických předmětů na základních a středních školách (Pedagogické fakulty).

- Národní ústav vzdělávání, Praha.

- Další instituce (školy, školicí střediska apod.).

Bohužel v současné době nezaznamenáváme mnoho studií, které jsou v této oblasti publikovány. Chybí zejména systematické studie (propracované učební texty, odborné knihy, výzkumné zprávy). Nemáme zatím ani žádnou instituci, která by v této oblasti plnila funkci národní autority. Výzkumné aktivity jsou spíše fragmentované, výzkumné týmy jsou výjimkou. Za tímto stavem je zřejmě vidět odklon zájmu mládeže o technické obory, zejména s novými možnostmi po roce 1989, kdy nastal obrovský zájem o humanitní obory, které v předchozí době zatlumeny. Současně se pro ni otevřely 
možnosti cestování a svobodného života. $V$ té době nebyl společenský požadavek ani zdroje financování na technické vzdělávání. Tento nepř́znivý vývoj si politici spolu $\mathrm{s}$ představiteli průmyslu začali uvědomovat $\mathrm{v}$ druhé polovině první dekády 21 . století. Začala se pomalu formovat jednotlivá odborná pracoviště. Pozitivním krokem byl v roce 2009 vznik recenzovaného vědecko-odborného časopisu JTIE (Journal of Technology and Information Education), který se zaměřuje na publikování výsledků teoretických studií, výzkumných aktivit a odborných prací v oblasti technického a informačního vzdělávání (http://jtie.upol.cz/index.htm). Krokem vpřed jsou i aktivity, které vyvíjí Národní ústav pro vzdělávání. Na jeho stránkách jsou k dispozici studie, které spadají i do rámce odborného technického vzdělávání (http://www.nuv.cz/vystupy/vydane publikace). Jedná se o metodické materiály i výsledky výzkumných aktivit. V některých př́padech se jedná o zpracované materiály do výuky vybraných témat př́slušných oborů a technických předmětů. Tím se dostáváme na úroveň speciálních (předmětových) didaktik. Některé oborově didaktické práce $\mathrm{v}$ této oblasti však oscilují $\mathrm{k}$ obecně didaktické rovině a aplikační potenciál je $\mathrm{v}$ nich nedostatečný.

V období 2000 až 2015 zaznamenáváme snahu posunout oborovou didaktiku technických předmětů dál a upevnit tak její místo v systému oborových didaktik. Vznikají učební texty a výukové opory pro potřeby výuky didaktiky technických předmětů (Čadílek, Loveček, 2005, Kropáč a kol, 2004, Friedmann, Pecina, 2012, Pecina, 2013, Pecina, 2014, Linkeschová, 2013). Dílčí výzkumná zjištění i teoretické studie jsou publikovány $\mathrm{v}$ některých časopisech (JTIE, LIFELONG LEARNING, celoživotní vzdělávání) a sbornících (mezinárodní kolokvium o řízení vzdělávacího procesu, Brno). Dílčí snahy zaznamenáváme i na úrovni diplomových a v některých př́ípadech i disertačních prací. Snaha výzkumníků se rovněž zaměřuje na projektové řešení a inovace $\mathrm{v}$ oblasti odborného technického vzdělávání. $V$ současné době probíhají některé projekty, které se zaměřují na reformu kurikulárních dokumentů $\mathrm{v}$ odborném technickém vzdělávání (projekt POSPOLU). Sledujeme tendence, které podporují rozvoj odborného technického vzdělávání na úrovni základních i středních škol (Např. střední odborná škola a vy̌šší odborná škola technická Chomutov je v současnosti společně se čtrnácti dalšími středními školami zapojena do unikátního projektu evropské unie „Přírodovědné a technické vzdělávání Ústeckého kraje“. V rámci projektu navštěvují žáci 8. a 9. ročníků partnerských základních škol střední odborné školy a mohou nahlédnout do prostředí a vzdělávací nabídky vybraných technických oborů.). Spolupráce mezi základními a středními školami $\mathrm{v}$ oblasti technického vzdělávání probíhá $\mathrm{i} \mathrm{v}$ jiných oblastech České republiky. Informace o řešených projektech v této oblasti lze nalézt v učitelských novinách a na stránkách Národního ústavu vzdělávání (www.ucitelskenoviny.cz, www.nuv.cz). Na Pedagogické fakultě MU byl v období 2011- 2013 řešen projekt pod názvem „Inovace bakalářského studijního oboru učitelství praktického vyučování“. Jeho součástí byla inovace obsahové náplně třiceti specializačních předmětů a návrh nových volitelných předmětů, včetně vytvoření učebních textů a výukových opor $\mathrm{k}$ těmto předmětům. Inovován byl i systém pedagogických praxí (http://upv.ped.muni.cz/). Výstupem v oblasti oborové didaktiky technických předmětů je publikace Z. Friedmanna a P. Peciny (2013) a navržený nový volitelný předmět Inženýrská pedagogika (Linkeschová, 2013, Ouroda, 2013). 
Reálným př́nosem do této oblasti je i studie $\mathrm{k}$ problematice pedagogických praxí technických oborů (Děcký, 2013).

\section{Vědeckovýzkumná činnost $\mathrm{v}$ didaktice odborných technických předmětů}

Oborová didaktika technických předmètů využivá v plném rozsahu vědeckovýzkumné metodologie pedagogických věd. Základním východiskem vědeckého výzkumu v oblasti didaktiky odborných technických předmětů jsou pedagogické tradice, práce dobrých učitelů technických předmětů a vědecké zkoumání (Drahovzal, Kilián, Kohoutek, 1997). Didaktický výzkum vychází z pozitivních zkušeností, ke kterým učitelé v minulosti dospěli. Práce učitelů technických předmětů jsou významný zdroj poznání. Tyto poznatky jsou však individuální a subjektivní (Drahovzal, Kilián, Kohoutek, 1997).

Pro didaktiku odborných technických předmětů a pedagogickou praxi mají smysl poznatky, které mají obecnou platnost. Tyto poznatky poskytuje pedagogický výzkum, což je vědecká činnost zaměřená na systematický popis, analýzu a objasňování edukační reality (Průcha, Walterová, Mareš, 2003). V České republice nemá oborově didaktický výzkum v oblasti technického vzdělávání takovou bohatou tradici jako v některých jiných zemích (Německo, USA, Velká Británie). V současné době bohužel nemáme dostatek informací a výzkumných zpráv, které by dokazovaly, že se výzkumné aktivity systematicky a permanentně směrují na oblast odborného technického vzdělávání.

Dále se zaměříme na vybrané výzkumy (průzkumy), jejichž dílčí části byly realizovány $\mathrm{v}$ projektech diplomových prací studia učitelství odborných předmětů na Pedagogické fakultě MU (Wasserburger, 2010, Tučková, 2011, Souček, 2015). Tyto průzkumy byly zaměřeny na využívání výukových metod učiteli odborných předmětů a aspekty rozvoje tvořivosti žáků $v$ technických předmětech. $\mathrm{V}$ oblasti rozvoje technické tvořivosti prostřednictvím projektové výuky publikoval práci J. Novotný a J. Zukerstein (2007). Předmětem zájmu našeho výzkumu byly výukové metody v práci učitelů technických předmětů na středních školách (Pecina, Svoboda, 2015).

J. Wasserburger (2010) provedl výzkum na středních odborných školách ve Vyškově a vybraných školách v Brně. Ve svém výzkumu zjistil, že učitelé odborných předmětů na středních odborných školách ve stavebních oborech aktivizující výukové metody používají. Avšak frekvence využívání didaktických her, brainstormingu a metody řešení problémových úkolů je relativně malá. Učitelé také zdůrazňují problémy se začleňováním těchto metod do výuky - časová tíseň, slabší žáci, nekázeň (Wasserburger, 2010, s. 71). Další důležitě zjištění je to, že učitelé zaměňují pojem „výukový problém“ s problémy kázeňskými, problémy $\mathrm{s}$ pochopením učiva, specifickými poruchami učení apod. (Wasserburger, 2010).

R. Tučková (2011) zjištovala, zda učitelé odborných předmětů použivají metody tvořivého vyučování (Tučková, 2011, s. 40). Dotazníkového výzkumu se zúčastnilo 124 respondentů. Výzkum zjistil, že učitelé se snaží metody tvořivého vyučování používat a že o nich mají povědomí. Problémem však je jejich malá frekvence využívání. Jejich využívání je ztíženo nedostatkem pomůcek a vybavení (Tučková, 2011, s. 64).

E. Hrabalová (2011) zjišt’ovala, jak jsou v práci učitelů odborných předmětů zastoupeny komplexní výukové metody (frontální výuka, partnerská výuka, skupinová a kooperativní výuka, brainstorming, projektová výuka, výuka podporovaná počítačem). Dotazníkového výzkumu se zúčastnilo 67 respondentů. Výsledky výzkumu jsou 
pozitivní. Učitelé bohatě kombinují všechny výše uvedené komplexní metody výuky, tedy jak klasické, tak metody podporující aktivní činnost žáků a rozvoj kreativity. Tyto metody využívají jak začínající učitelé $\mathrm{s}$ délkou praxe do 2 let, tak zkušenější kolegové.

V našem výzkumu jsme zjišt'ovali, jaké výukové metody tvořivé výuky používají učitelé technických odborných předmětů (mimo praktické vyučování) na středních odborných školách a jaké poznatky o vybraných metodách mají. Výzkum byl realizován v Jihomoravském kraji (Pecina, Svoboda, 2015). Distribuováno bylo celkem 250 dotazníků na území Jihomoravského kraje. Výzkum (dotazník a řízené rozhovory) byl proveden na 13 středních školách. Ze získaných údajů vyplývá, že z klasických (tradičních) výukových metod jsou nejvíce používanými metodami výklad (vysvětlování, popis) a zápis do sešitu. Ve vysoké míře učitelé také využívají diskusní metody (rozhovor, dialog, diskuse), což je velmi pozitivní zjištění. Často je také používána metoda samostatné práce $\mathrm{s}$ materiály. Metoda práce $\mathrm{s}$ počítačem je využívána v rozmanité míré. Výzkum zjistil, že málo jsou využívány metody školního laborování a experimentování, pozorování předmětů a jevů a praktických ukázek, což není pro výuku technických předmětů př́lišs pozitivní zjištění. Z metod aktivizující výuky učitelé zařazují s různou intenzitou práci ve skupinách, samostatnou práci a projektovou metodu. Relativně málo zařazují (podle jejich vyjádření) řešení problémových úkolů. V minimální míře učitelé využívají didaktické hry, velká část je nevyužívá vůbec. Z výzkumu tedy vyplynulo, že učitelé berou tvưrčí aktivitu žáků jako důležitou a potřebnou, avšak metody tvořivé výuky se využívají relativně minimálně. Je však patrná snaha tyto metody do výuky aplikovat (Pecina, Svoboda, 2015). Na základě výzkumu lze doporučit zařadit do výuky vybrané aktivizující metody (didaktické hry, řešení problémových úkolů) a metody praktické (školní experimentování a laborování) zasazené do heuristické výuky.

\section{Diskuze a závěry ke směřování dalšího rozvoje}

Společnost pocituje nedostatek kvalitních absolventů technických škol. Proto se vedou diskuse mezi zástupci firem a průmyslu s resortem školství o další podpoře a rozvoji technického vzdělávání. V současné době je tak patrná tendence podporovat (proklamace) odborné technické vzdělávání na úrovni základních, středních i vysokých škol. Didaktika odborných technických předmětů proto zjevně nabude na významu a otevře se prostor $\mathrm{k}$ jejímu rozvoji. Národní ústav vzdělávání realizuje projekty, které jsou zaměřeny na propojení a zefektivnění teoretické a praktické výuky technických oborů. Strategickým cílem je podpora magisterských studijních oborů se zaměřením na odborné vzdělávání (učitelství odborných předmětů), včetně učitelství praktického vyučování v bakalářském stupni, a podpora doplňujících pedagogických studií (DPS) pro absolventy technických vysokých škol. Pro posílení technických oborů na stř̌edních školách je potřeba neopomíjet předměty technického charakteru již na základních školách. Na tuto situaci je třeba připravovat učitele všech typů s předstihem. Proto je potřeba na pedagogických ale i technických fakultách posílit personálně i odborně týmy zabývající se problematikou technického vzdělávání. Oboroví didaktici technických předmětů musí být lidé jak s kvalitním pedagogickým vzděláním, tak se vzděláním $\mathrm{v}$ oblasti technických věd. Je výhodou praktická zkušenost $\mathrm{z}$ výuky 
na střední škole. Nebezpečím didaktiky technických předmětů je totiž její „ustrnutí“, neschopnost dalšího rozvoje a také inklinace $\mathrm{k}$ obecně pedagogickým disciplínám. Jedná se o oborovou didaktiku, a proto ji nelze suplovat např. jen obecně didaktickými poznatky a naopak ji nelze budovat na prezentacích konkrétních ukázek vzdělávacích cílů, obsahu a metodických rozborů příslušných technických věd.

Další práce $\mathrm{v}$ didaktice odborných předmětů by měla směrovat ke kooperaci, fundovaným výzkumným aktivitám i tvorbě propracovaných učebních textů a výukových opor. Výzkumná zjištění ukazují, že je žádoucí se mimo jiné zaměřit na technologii výuky, na aplikaci aktivizujících a komplexních výukových metod a na otázky rozvoje technické tvořivosti žáků. Stávající systém didaktiky technických předmětů stojí před mnoha požadavky dnešní doby. Je třeba reflektovat rychlý vývoj vědy a techniky, nové poznatkové struktury, vznik nových oborů, aspekty využití soudobých multimediálních výukových prostředků a mnoho dalšího. Snaha odborníků v této oblasti by se měla zaměřit na institucionální zakotvení tohoto oboru, vytvoření národní autority. Tím se otevře prostor k rozvoji nejen širši oborové didaktiky, ale také jednotlivých předmětových didaktik v rámci oboru. Ukazuje se, že praxe technického vzdělávání to jednoznačně vyžaduje.

Dalším žádoucím krokem je vzájemná kooperace vysokoškolských týmů a firemních vzdělávacích pracovišt' $s$ ambicí a ochotou řešit vědeckovýzkumné a rozvojové projekty. Vysokoškolská pracoviště by měla mít možnost prosazovat zaměření doktorských studijních programů voboru pedagogických věd na didaktiku technických oborů (pedagogické fakulty ve spolupráci s technickými univerzitami).

\section{Závěr}

Předložená studie analyzuje historický vývoj, aktuální stav a možný vývoj didaktiky technických předmětů v České republice s důrazem na vědeckovýzkumnou činnost jako základ její vědeckosti. Pozornost byla zaměřena zejména na klíčové momenty v jejím vývoji a současném stavu. Prezentována jsou i vybraná výzkumná zjištění k problematice výukových metod a technické tvořivosti žáků $\mathrm{v}$ odborných technických předmětech na středních školách. Ze zjištěných výzkumných údajü vyplývá, že se do praxe odborného technického vzdělávaní stále nedaří v odpovídající míře aplikovat vybrané aktivizující a komplexní výukové metody, metody tvořivé výuky. Pro zachování dostatečné technické kvalifikace pracovníků $\mathrm{v}$ České republice je tedy nezbytná podpora vzdělávání učitelů technických odborných předmětů včetně rozvoje oborové didaktiky odborných technických předmětů.

\section{Literatura}

Amabile, T. M. (1989). Growing up creative: Nurturing a lifetime of kreativity. New York, Crown. In: Lokšová, I., Lokša J. Tvořivé vyučování. Praha: Grada Publishing, 2003.

Bajtoš, J., \& Pavelka, J. (1999). Základy didaktiky technickej výroby. Prešov: Prešovská univerzita.

Čadílek, M., \& Loveček, A. (2005). Didaktika odborných predmětů. Brno: Akademické nakladatelství CERM.

Děcký, J. (2013). Pedagogická praxe 1. Brno: PdF MU. 
Drahovzal, J., Kilián, O., \& Kohoutek, R. (1997) Didaktika odborných předmètů. Brno: Paido.

Friedmann, Z. (1993). Didaktika technické výchovy. Brno: Masarykova univerzita.

Friedmann, Z., Pecina, P. (2013). Didaktika odborných predmětů technického charakteru. Brno: PdF MU.

Hrabalová, E. (2011). Problematika využití komplexnich metod ve výuce odborných předmětů. Diplomová práce, Brno: MU. Vedoucí práce Mgr. Pavel Pecina, Ph.D.

Kilián, O. (2008). Základní otázky oborových didaktik. In" Podpora rozvoje oborových a predmètových didaktik v odborném vzdèlávání. "Praha: NUOV. s. 9- 18.

Kropáč, J., Kubíček, Z., \& Hajda, V. (1996). Didaktika technických předmětů vybrané kapitoly. Olomouc: UP.

Kropáč, J. (Eds.) (2004). Vybrané kapitoly z didaktiky technických predmětů. Olomouc: UP.

Linkeschová, D. (2012). Úvod do moderní inženýrské pedagogiky. Brno: MU.

Melezinek, A. (1994). Inženýrská pedagogika. Praha: ediční středisko ČVUT.

Mošna, F.(1992). Didaktika technické výchovy. 1. vyd. Praha: Univerzita Karlova.

Mošna, F., \& Rádl, Z. (1996) Problémové vyučováni a učení v odborném školství. Praha: Pedagogická fakulta UK.

Meyer, H. (2000). Unterrichtsmethoden I, II. Frankfurt am Main: Cornelsen Verlag Scriptor.

Nezvalová, N. (2011). Didaktika fyziky v České republice: trendy, výzvy a perspektivy. In" Pedagogická orientace", roč. 21, č. 2, s. $171-192$.

Novotný, J., \& Zukerstein, J. (2007). Rozvoj technicky orientované tvořivosti pomocí projektových metod. In: XXV. Mezinárodni kolokvium o řizení osvojovacího procesu zaměrené k aktuálním problémům vědy, výchovy, vzdělávání a rozvoje tvưrčího myšlení.

Brno: Univerzita obrany.

Ouroda, K. (2013). Inženýrská pedagogika. Nové Město nad Metují: KNOPP.

Průcha, J. (1978). Teoretická východiska a zásady tvorby základních pedagogických dokumentù. Praha: Výzkumný ústav odborného školství.

Pecina, P. (2012). Didaktika praktického vyučování pro technické obory - 1. díl Výuková opora. Brno: PdF MU.

Pecina, P., \& Sládek, P. (2013). Pojetí a struktura didaktiky technických odborných předmětů pro střední odborné školy. In. Břehovský, J., Novotný, J. Zukerstein, J. Strategie technického vzdèlávání v reflexi doby 2013. Ústí nad Labem :UJEP v Ústí nad Labem. s. 131 - 141, 10 s.

Pecina, P. (2013). Projektování a připrava výuky v odborném technickém vzdělávání na střednich školách. Brno: PdF MU.

Pecina, P. (2014). Didaktika odborných predmètů (úvod do oborových didaktik, didaktika odborných predmètů) pro magisterské studium učitelství odborných predmětů. Výuková opora. Brno: PdF MU.

Pecina, P., \& Svoboda, I. (2015). Aspekty učení v didaktice odborných předmětů a praktického vyučování $\mathrm{v}$ kontextu výukových metod. In. Lifelong Learning Celoživotni vzdělávání, Brno: Mendelova univerzita v Brně, roč. 5/2015, č. 2, s. 172-200. Píšová, M. (2011). Didaktika cizích jazyků: otázky identity In "Pedagogická orientace", roč. 21 , č. 2 , s. $142-155$. 
Scigiel, M. (1986). Didaktika technické výchovy. Brno: Univerzita J. E. Purkyně. Souček, P. (2015). Problematika využiváni aktivizujicich metod ve výuce odborných předmětů v oboru podlahářr. Diplomová práce. Brno: MU. Vedoucí práce Mgr. Pavel Pecina, Ph.D.

Stuchlíková, I., \& Janík, T. (Eds.). (2015). Oborové didaktiky: vývoj - stav-perspektivy. Brno: MU.

Trna, J. (2005). Nastává éra mezioborových didaktik? Pedagogická orientace, Brno: Konvoj, roč. 2005, č. 1, s. 89-97.

Tučková, R. (2011). Rozvoj tvořivosti žáků ve výuce odborných předmětů. Diplomová práce. Brno: MU. Vedoucí práce Mgr. Pavel Pecina, Ph.D.

Turek, I. (1990) Didaktika technických predmetov. Bratislava: Slovenské pedagogické nakladat'elstvo.

Kolektiv autorů (2001). Technická tvořivost a výuka pracovních činností ve školách: sborník př́íspěvků z odborného semináře. Brno: CERM.

Vlášek, K. (1976). Systémy odborného výcviku. Praha: Výzkumný ústav odborného školství.

Vlášek, K., \& Průcha, J. (1978). Obecný model průběhu osvojování pracovnich činností v odborném výcviku. Praha: Výzkumný ústav odborného školství.

Wassserburger, J. (2010). Aktivizujici výukové metody vekonomických a odborných predmětech stavebních oborů. Diplomová práce. Brno: MU. Vedoucí práce Mgr. Pavel Pecina, Ph.D.

Stálá pracovní skupina AK pro oborové didaktiky. (2015). [online]. Retrieved from: http://www.akreditacnikomise.cz/cs/oborove-didaktiky.html.

JTIE - Journal of Technology and Information Education. (2015). [online]. Retrieved from: http://jtie.upol.cz/

Národní ústav vzdělávání. (2015). [online]. Retrieved from: http://www.nuv.cz/ Učitelské noviny. (2015). [online]. Retrieved from: http://www.ucitelskenoviny.cz Pedagogická fakulta Masarykovy univerzity. (2015). [online]. Retrieved from: www.ped.muni.cz 